\title{
А.Ю. Хабутдинов
}

\section{Лидерство у мусульман округа Оренбургского магометанского духовного собрания в свете теории Ибн Халдуна об асабийи: опыт построения гипотезы}

В данном исследовании делается попытка рассмотрения функционирования групп элиты у мусульман Волго-Уральского региона, объединенных в округ Оренбургского магометанского духовного собрания (ОМДС, 1788-1917) с точки зрения теории Ибн Халдуна об асабийи. Ключевым здесь является тезис Ибн Халдуна: «не родство является причиной объединения людей в группу (род, племя), а объединение, вызванное необходимостью удовлетворения насущных материальных потребностей, приводит к осознанию родства» [Игнатенко, 1980, c. 70-72]. При этом, «родство - нечто иллюзорное, чего нет в действительности» [Игнатенко, 1980, с. 136]. Можно согласиться с мнением А.А. Игнатенко, что «в концепции Ибн-Хальдуна понятие "асабийя" имеет два значения. В “Пролегоменах"1 это понятие и обозначает, во-первых, “группу”, “группировку людей”... Ибн-Хальдун пишет, например, что несколько сравнительно малых асабий ${ }^{2}$ (т.е. группировок) объединяются в большую асабийю... Во-вторых, асабийя у Ибн-Хальдуна - это еще и связь, определенные отношения, которые “привязывают" членов группировки (асабийи) друг к другу так, что они образуют единый организм» [Игнатенко, 1980, с. 71]. Ибн Халдун постулирует, что «располагающий асабийей, достигнув какой-то степени, стремится к высшей... Но один он неспособен к этому, а только через группировку, в которой он является тем, за кем следуют» [Игнатенко, 1980, с. 137]. При этом Ибн Халдун также указывает, что «религиозный призыв не может осуществляться без наличия группировки» [Игнатенко, 1980, с. 48].

Теперь обратимся к истории мусульман Волго-Уральского региона в XVIII - начале XX в. В 1710-е гг. в Поволжье окончательно перестал существовать класс татарских мусульманских феодалов. В результате этого среди мусульман региона возникло состояние вакуума 
власти. Это положение было изменено Екатериной II, создавшей в 1770-1790-е гг. привилегированные группы татарского общества: дворянство (в Приуралье), духовенство и буржуазию. Только буржуазия обладала необходимыми финансовыми возможностями и структурами для руководства жизнью нации в лице органов самоуправления в Казани и Каргале. Вначале были возможны два варианта лидерства, иллюстрацией которых является судьба руководителей двух каменных мечетей Казани, чье строительство было разрешенно Екатериной II в 1767 г. Ахун Казани, имам и мударрис 1-го прихода, историк Ш. Марджани особо указывает, что со времен Казанского ханства в городе не было стабильной мечети. В случае Первой мечети (затем Юнусовской, ныне мечеть Марджани) строительство велось на деньги группы имамов, занимавшихся бизнесом, и буржуазии. [Марджани, 1900, с. 12]. Вторая мечеть (будущая Апанаевская) строилась на деньги первого председателя Казанской татарской ратуши Якуба б. Султангали [Марджани, 1900, с. 12]. Однако его род вскоре прервался. Соответственно мечети стали известны по именам патронирующих их родов как «Юнусовская» и «Апанаевская». Городские медресе находились (особенно в 18301860-е гг.) обычно под патронажем одного конкретного бая, фактического хозяина махалли, который монопольно контролировал ее внутреннюю жизнь.

С созданием в 1788 году ОМДС имамы и улемы ставились под контроль государства, полностью определявшего их кадровый состав. Если учесть, что в России уже существовала свобода вероисповедания для лиц, официально зарегистрированных как мусульмане, то этот указ устанавливал механизм надзора за духовными лицами, при этом основное внимание уделялось их лояльности Российскому государству («люди, в верности надежные...»). Наместник (генерал-губернатор) Симбирской и Уфимской губерний барон О.А. Игельстром разработал Положение об ОМДС, в котором жестко определялся механизм получения «духовного чина» имама и ахуна. После избрания сельским обществом нужно было получить документ, удостоверяющий лояльность и указывающий о проживании в данном селении и губернии, от уездного земского исправника или кантонного начальника. Об этом сообщалось наместническому (губернскому) правлению. С санкции последнего испытуемый мог держать экзамен в ОМДС в присутствии губернских властей в лице двух верхней расправы (суда) заседателей. После экзамена его результаты утверждало наместническое правление. На уезд должно было приходиться не более двух ахунов. Причем под их наблюдением должны были находиться мечети, религиозные школы и их служители [Материалы..., 1960, с. 563-564; Азаматов, 1999, с. 26-27].

К 1800 г. в ОМДС подвергся экзамену 1921 человек, что фактически обозначало контроль над абсолютным большинством приходов. Только за 1791 г. экзаменам подверглись 789 человек, включая 7 ахунов, 2 помощников ахунов, 51 мухтасиба, 527 мулл (имамов), 9 мудар- 
рисов, 339 азанчеев (муэдзинов), 10 фаррашей и 15 муджавиров [Материалы..., 1960, с. 684]. Тем самым, в краткие сроки возникает стабильная профессиональная группа «указных (т.е., признанных государством. - A. X.) мулл», которых можно условно обозначить как «мусульманское духовенство».

К началу XIX века, обеспечив строительство мечетей, содержание мектебов и медресе, обучение и подбор мулл и мударрисов, монополизировав торговлю, скупку и обработку сырья на территории Заказанья, буржуазия приобретает контроль над рядом традиционных сельских общин, заменив здесь мурз и духовенство. Духовное Собрание обладало лишь четырьмя богословами (муфтий и три казыя), и без учебного заведения и стандартной программы стало скорее официальным учреждением, где указы на духовное звание зачастую продавались. Ш. Марджани прямо называл отцом этой традиции муфтия Мухаммеджана Хусаинова [Марджани, 1900, с. 289]. При этом М. Хусаинов стремился создать асабийю, охватывающую весь округ ОМДС, и замкнуть ее лично на себя.

Отличительной особенностью структуры ОМДС было отсутствие эффективного механизма контроля за положением на местах. Среднее звено духовенства - ахуны, как правило, были разбросаны по деревням и не оказывали никакого влияния на местное духовенство и власти на уездном и губернском уровне. В 1804 г. муфтий М. Хусаинов предложил проект централизации духовных органов на местах. Он выступал против контроля со стороны местных властей над вопросами, входившими в компетенцию Духовного Собрания, предлагал создать в СанктПетербурге коллегию по мусульманским делам и ее филиалы в основных мусульманских губерниях, рекомендовал предварительное рассмотрение судебных дел в отношении духовенства в Духовном Собрании. Предложения Хусаинова сводились к уподоблению статуса и структуры миллета мусульман Оренбургского Духовного Собрания оттоманским миллетам.

Первого муфтия ОМДС заслуженно упрекают в авторитарности. Широко известно и его взяточничество. Поэтому мысли сместить его возникали даже среди казыев ОМДС. М. Хусаинов стремится выстроить прямые отношения с верховной властью и создать общероссийскую структуру с центром в имперской столице. Вначале в качестве связующего звена он использует О.А. Игельстрома, но тот покидает край.

По своим земельным владениям и доходам М. Хусаинов фактически становится крупнейшим мусульманским землевладельцем края. По Указу императрицы Екатерины II от 26 января 1793 года Хусаинов получил право покупать у башкир земли и «заселять оные покупаемыми за границей иноверцами, присвоив ему и потомству его право продавать оных, с тем однако предостережением, чтобы покупка и продажа таковых людей простиралась токмо до иноверцев не христианского исповедания». М. Хусаинов обладал обширным помещичьим хозяйс- 
твом, недвижимостью в Уфе и Оренбурге. По некоторым данным, после смерти он оставил огромную по тем временам сумму в 50000 рублей [Мухетдинов, 2011, с. 16-17]. Тем самым, он, помимо прочего, стремился создать финансовую базу для своей асабийи.

В 1803 г. М. Хусаинов добивается замечаний в адрес губернской администрации от молодого императора Александра I. Российский правитель обосновывает необходимость уважения императора как представителя многочисленных мусульманских народов. Возможно, этот конфликт был вызван тем, что Оренбургское губернское правление прямо поддержало ахуна Г. Габдрахимова (муфтий после смерти М. Хусаинова в 1825-1840 гг.) в его конфликте с муфтием, пик которого пришелся на 1802-1805 гг. [Азаматов, 1999, с. 49-50; Денисов, 2009, c. 80-81]. М. Хусаинов проиграл в этом бою, но сохранил свой пост, и с 1811 г. муфтии стали подсудны только Правительствующему сенату.

В 1808 г. в Казанской и в 1822 г. в Оренбургской губернии у местной администрации и мусульман также возникали идеи создания губернских духовных правлений. В 1822 г. чиновники Оренбургского губернского правления предлагали создать в Петербурге коллегию ахунов, имеющую право апелляционного суда по вопросам церковного права. Следовательно, уже в начале XIX века мусульмане понимали потребность автономии духовных властей на местах, наличия строгой централизации духовной власти и соответствия структур духовных органов административно-территориальному устройству России. Все эти проекты не были реализованы, и практически единственным механизмом контроля со стороны Духовного Собрания было временное изъятие указа.

Наиболее серьезной попыткой создания асабийи, альтернативной асабийе ОМДС, возглавляемой М. Хусаиновым, стала деятельность имама деревни Ура Казанской губернии Хабибуллы б. Хусаина аль-Уруви. Мулла Хабибулла учился в Бухаре и Кабуле вместе с будущим муфтием М. Хусаиновым, получил в Кабуле титул шейха. Благодаря поддержке губернских властей, ему удалось занять ключевой пост имама мечети на Макарьевской ярмарке, которая тогда была основным торговым центром татарского мира. При этом он сместил с данного поста назначенца муфтия М. Хусаинова и своего брата. В это время имамы Ярмарочной мечети ежегодно назначались из числа лояльных муфтию имамов других регионов. Это было мощным финансовым подспорьем, как для имамов, так и для самого муфтия. Нижегородские же власти и мусульмане предпочитали иметь стабильного имама [Хабутдинов, 2010, с. 51-55]. В 1804 г. Хабибулла отправился в Петербург, где добивался создания самостоятельных духовных правлений в Пензенской, Саратовской, Симбирской и Казанской губерниях. Саратовское губернское правление предлагало вариант создания такого рода Собрания при условии его номинального подчинения ОМДС. Штаты его правления фактически были аналогичны штатам ОМДС, причем пред- 
полагалось введение сана муфтия. Отличие состояло в том, что правление должно было финансироваться за счет самих мусульман. В 1813 г. казанский губернатор добился от князя А.Н. Голицына поддержки Хабибуллы б. Хусаина [Фахретдин, 2005, с. 290]. Однако административный ресурс муфтия ОМДС М. Хусаинова и неудачное использование Хабибуллой суфийского термина «халифа» (воспринятое властями как претензии на полномочия османского султана и халифа) блокировали его деятельность [Азаматов, 1999, с. 32-33; Марджани, 1900, с. 190-193].

Хабибулла б. Хусаин развернул свою деятельность главным образом среди мишарского населения, где приобрел много шакирдов и муридов. Он был ярко выраженной харизматической личностью. Люди целовали даже следы от полозьев его саней и колес телеги, его могила превратилась затем в центр поклонения для мишар. В родной Уре ему удалось создать ханаку, то есть постоянный центр для своих многочисленных муридов. Пример отдаленных от городов и властей мишарских деревень, где муллы сами контролировали свои приходы, вдохновил Хабибуллу б. Хусаина. Ему не удалось открыть признанное властями Духовное Собрание, объединяющее мусульман между Волгой и Окой. Но он сам, как суфийский шейх, создал наиболее адекватную форму организации и упрочения Ислама среди мишарского населения, жившего чересполосно с нетатарами. Таким образом, в это время ишанизм стал практически единственной формой самосохранения группы татар, изолированной от основного ядра татарского населения. В 1860-е гг. Х. Фаизханов как очевидец писал, что: «целуют землю, там, где ступала нога Хабибуллы Ури, и, направляясь на кладбище Уры, едят землю с его могилы».

Самым известным эпизодом деятельности Хабибуллы б. Хусаина является его борьба против выдающегося улема и мударриса Абдуннасыра Курсави. Последний обучался у другого улема - суфия тариката накшбандийа-муджаддидийа шейха Ниязкул ат-Туркмани из Бухары, фактического соперника Фаизхана ал-Кабули. У этого бухарского шейха учились Абдуннасыр Курсави, Нигматулла Тукаев, мударрис медресе при мечети Иске-Таш в Казани Фазыл аль-Кизляви, основатель медресе в Стерлитамаке Шарафуддин б. Зайнуддин аль-Эстерли. Эта группировка отличалась своей сплоченностью. Их центром было медресе Мачкара в Заказанье. Таким образом, для регионов со слабо развитой городской сетью типа горной стороны Волги, Закамья и Приуралья именно суфии тариката накшбандийа сыграли основную роль в развитии образования.

Таким образом, сторонники муфтия в Поволжье жестко контролировали только медресе Мачкары и часть приходов Казани, а М. Хусаинов был хозяином Приуралья. В итоге асабийа М. Хусаинова, опирающаяся на ресурсы государства, победила асабийю Хабибуллы б. Хусаина, опирающуюся на суфийские связи, которая оказалась неспо- 
собна создать Духовное Собрание [Хабутдинов, 2010, с. 51-55]. Однако М. Хусаинов одержал победу только при жизни, так как после его смерти ОМДС в 1824 г. возглавил его давний соперник и противник ахун Оренбурга Г. Габдрахимов, то есть в асабийной группе ОМДС произошла радикальная смена лидерства

Необходимость наличия сильного лидера в махалле четко видна на примере двух описаний медресе при Первой мечети. В 1816 г. указывается, что его строителем был казанский купец третьей гильдии ахун Ибрагим Худжашев (Худжаши). Ибрагим Худжаши (ум. в 1826 г.) с 1794 г. стал имамом Первой Соборной (Юнусовской) мечети и ахуном Казани. По утверждениям Ш. Марджани и Р. Фахретдина, он был крупным специалистом по мусульманскому богословию, вынес ряд судебных приговоров в рамках семейного права, приложил много усилий по распространению и соблюдению религиозных обычаев и обрядов мусульманским населением Казани и уезда [Фахретдин, 1904, с. 227-237]. Деятельность Ибрагима Худжаши можно рассматривать как попытку создания региональной асабийи в зоне Казанского Поволжья. Однако по сенатскому указу от 31 августа 1826 г. мусульманским духовным лицам и Оренбургского, и Таврического муфтиятов в период пребывания их в «духовном статусе» было рекомендовано не заниматься «торговыми промыслами» [Ислам в Российской империи, 2001, с. 72-74].

Итак, имамам округа ОМДС запретили заниматься торговлей. То есть их лишили принципиальной экономической основы асабийи. Вдобавок они не обладали традиционной для мусульманского мира системой вакфов. Большая часть вакфов была конфискована еще сразу после уничтожения Казанского ханства, и окончательно этот процесс был завершен в период правления Анны Иоанновны (17301740 гг.). В этом заключалось коренное отличие имущественного положения мусульманского духовенства от православного духовенства, а также от духовенства в мусульманских государствах. По утверждению О.Г. Большакова, «превращение вакфов в основной источник существования культовых учреждений (примерно с XII в.) способствовало профессионализации и консолидации лиц, связанных с мусульманским культом, в особую социальную группу, которую условно можно назвать мусульманским духовенством. В XIX в. в Османской империи примерно $1 / 3$ всех земель относилась к категории вакфов» [Ислам, 1991, с. 45]. Это способствовало коррупции среди руководства ОМДС. Казый ОМДС Р. Фахретдин в 1905 г. на съезде «Голяма жэмгыяте» при ОМДС указывал: «А самые плохие, самые неспособные люди достигают больших высот, под сенью заступничества прекрасных любимчиков с желтыми зубами, красивыми лицами». Сложность и высокая цена поездки в Уфу, необходимость давать взятки при сдаче экзаменов отсекла от постов имамов образованных, но финансово не обеспеченных людей. К тому же выходцы из низов не 
могли себе позволить долголетнее обучение в медресе вдали от дома. Учеба в Бухаре, где к тому же наряду с расходами на поездку нужно было приобретать худжру (комнату) в медресе, становилась труднодоступной из-за еще более высокого имущественного ценза. В отсутствие вакуфной системы имамы не могли финансировать талантливых выходцев из низов. Имамы к тому же должны были обращаться за финансовой помощью к буржуазии для поддержания жизни приходов. Поэтому «бухара йортучеляр» (торговцы с Бухарой) все более усиливали контроль над жизнью приходов, особенно в 18301860-е гг. Уже в 1835 г. утверждается, что училище 1-го прихода Казани содержится на счет казанского купца Губайдуллы Юнусова [Медpece, 2007, с. 15]. Таким образом, со 2-й четверти XIX в. запрет для имамов заниматься торговой деятельностью неизбежно породил их зависимость от купцов. Имам должен был быть лоялен как баю, так и ОМДС. Таким образом, асабийа ОМДС лишилась стабильного самофинансирования и, следовательно, самостоятельности и владычества в основных городских центрах.

В годы «Великих реформ» в 1867 г. муфтий ОМДС Салим-Гирей Тевкелев представил проект «О правах магометан по вероисповеданию» [Хабутдинов, 2010, с. 101-104]. Здесь он фактически выступает за превращение махалли в самодостаточную общину по образцу деревни государственных крестьян, созданную реформой графа Киселева 18371841 гг. и близкой ей реформой помещичьих крестьян 1861 г. По его проекту возникает должность назыра, как попечителя. В проекте указывается, что «Всякий приход... избирает назыра - попечителя мечети и молитвенного дома - сроком менее трех лет, главная обязанность которого заключается в попечении о средствах мечети и школы, ежели таковая при мечети существует, и попечении [о] благотворительных учреждениях прихода» (п. 13). «Состоящим при мечетях и молитвенных домах духовным лицам и назырам вменяется в обязанность: заведовать внутренним устройством и хозяйством мечетей, молитвенных домов, находящихся при них медресе, школ и благотворительных заведений, где они существуют, каковы богадельни [для] престарелых, сирот и увечных» (п. 14). Назыру «будет предоставлено, собирать все рода добровольных приношений как для мечети, так для школ и для благотворительных учреждений, каковым пожертвованиям должен вести счет по каждому предмету отдельно, не смешивая пожертвования в пользу мечети с пожертвованиями на школу и на благотворительные учреждения. Назыр же обязывается вести приходо-расходные книги всех вообще пожертвований, каковые счета ежемесячно должны быть засвидетельствованы и подписаны муллой и муэдзином, и в случае желания прихода, по избранию депутатов от прихода, и повторяемы оным» (п. 15).

С.-Г. Тевкелев фактически стремится возродить традиции упраздненных башкирских кантонов, где кантонное начальство в лице сотских (1798-1838, 1863-1865) и деревенских начальников (1838-1863) 
было выше имамов и контролировало сферу собственности [Асфандияров, 2005]. Самостоятельность власти назыра определялась и отсутствием механизма его смещения. В отличие от власти кантонного начальства, она была подконтрольна общинникам, но резко сокращала власть имамов.

Сам С.-Г. Тевкелев был владельцем более трех тысяч десятин земли и в 1848-1851 гг. был избран предводителем дворянства Бугульминского уезда Оренбургской губернии. Для него упразднение Башкирско-мещеряцкого войска в 1865 г. означало утрату контроля дворянства над жизнью общинников-вотчинников (кстати, официально называемых «асаба»).

По проекту С.-Г. Тевкелева ахуны не обладают контрольной функцией в сфере семейного права, которая передается в ведение самого ОМДС: «Магометанскому собранию подлежит, кроме того, обсуждение и решение следующих дел: семейные неудовольствия супругов, прелюбодеяния, браки против желания, разводы, разрешение всех жалоб на мулл и ахунов по делам веры, разрешение споров по наследству, ежели спорящие не желают обращаться в судебные места, а хотят рассудиться по шариату; рассмотрение дел между детьми и родственниками в пределах семейного быта» (пункт 55). ОМДС, а не ахунам, передается и функция ревизий. По проекту, ахуны «утверждаются в должностях по представлению муфтия и местным начальством губернии» (п. 22). С.-Г. Тевкелев отказывался от принципа избрания муфтия, тот по представлению Министерства внутренних дел утверждался указом императора, а «помощник его - по представлению муфтия к Министру внутренних дел высочайшим объявленным Правительствующим Сенатом повелением» (п.34). С.-Г. Тевкелев особо указывал, что «на должности муфтия и его помощника могут быть назначены не только духовные, но и другие достойные из магометанских мурз и дворян лица, пользующиеся уважением магометанского общества, хотя бы они дотоле не имели духовного звания» (п. 35). Такая постановка вопроса обозначала фактическую потерю монополии улемов на руководство ОМДС. Мурзы превращались в основную группу национальной элиты в округе ОМДС, контролируя посты муфтия, помощника муфтия.

ОМДС передаются и функция ревизий: «Помощник муфтия и муфтий ежегодно должны по возможности обревизовать медресе и мечети, обращая особое внимание как на познание учащих и учащихся, так и на самое направление образования, и отчет о ревизиях своих обязаны представлять по окончании оных в Департамент иностранных исповеданий» (ДДИИ) [Проект..., 2009, с. 18-28]. Тем самым выстраивался новый вариант асабийи, контролировавший недвижимость, сферу образования и нормы семейного права. Здесь власть принадлежит мурзам-дворянам, а не улемам-имамам. Но проект Тевкелева, как увеличивающий права ОМДС, был торпедирован чиновниками. 
В 1860-1870-е гг. у татар к лидерству в махаллях приходил новый средний класс, не столь богатый, но более многочисленный и ориентированный на местные рынки. Ш. Марджани удалось создать классический тип медресе, в котором мударрис являлся абсолютно самостоятельной фигурой. Эта идея вызвала сопротивление И. Юнусова, лидера наиболее влиятельного рода в 1-м приходе Казани. Конфликт сопровождался взаимными обвинениями и даже поджогом медресе [Марджани, 1900, с. 18-20]. В 1876 г. с помощью инспектора татарских, башкирских и киргизских школ Казанского учебного округа В. Радлова удалось добиться одобрения со стороны МВД «Проекта правил для управления имуществом медресе прихода 1-й соборной мечети г. Казани». На базе медресе был создан мутаваллиат (попечительский совет) в составе двух прихожан, мударриса и учителя русского языка. Членов мутаваллиата избирали на общем собрании прихожан сроком на три года. В обязанности попечительского совета входило: управление имуществом, сбор, принятие и распределение пожертвований, взаимодействие с органами власти, ежегодный отчет перед мусульманами общины, которые имели право создавать ревизионные комиссии. [Салихов, 2006, с. 221-222]. Модель Марджани представляла собой модель научную и образовательную. Он вывел медресе из-под подчинения конкретному баю. Это был первый и уникальный случай такого рода в округе ОМДС, который предлагал модель новой асабийи, контролируемой улемом-имамом [Хабутдинов, 2010, с. 140].

Реформа мусульманской благотворительности у татар в начале прошлого века преследовала своей целью стабильное финансирование джадидских преобразований в конфессиональной школе. Выборный мутаваллиат Пятой махалли г. Казани, где размещалось медресе «Мухаммадия», благодаря вакуфным пожертвованиям купцов М.И. Галеева, Х. Шарафутдинова, А.Г. Хусаинова, Г.И. Утямышева, имама Г.М. Галеева (Г. Баруди) сделал общину собственником недвижимого имущества общей стоимостью в 150000 рублей [Салихов, 2001, с. 284-292]. Имам Г. Баруди (муфтий ЦДУМ в 1917-1921 гг.) создавал местную асабийю, где ключевую роль играли имамы и мударрисы. Модель для нее он во многом заимствовал у своего муршида Зайнуллы Расули (1833-1917). В 1884 г. З. Расули был избран имамом пятого прихода Троицка и возглавил медресе, названное его именем. Наиболее известным муридом 3. Расули стал Галимджан Баруди. Особое внимание 3. Расули уделял медресе Г. Баруди «Мухаммадия», заложив в 1891 г. первый камень в его основание. В свою очередь, сын 3. Расули Габдуррахман был муфтием ЦДУМ в 1936-1950 гг. Огромный авторитет 3. Расули, его личные отношения с муридами позволяли ему в определенной степени контролировать жизнь мусульман на огромных территориях. К нему стекались ученики из Сибири, из Туркестана, Казахстана, Дагестана и Казани [Фахретдин, 1917, с. 41]. 
3. Расули воплотил в жизнь модель классической городской махалли. В пятом приходе города Троицка Оренбургской губернии он создал целую мусульманскую инфраструктуру, включавшую медресе «Расулия», суфийскую ханаку, типографию и библиотеку. В пользу медресе он создал вакф, куда передал 19000 руб. из своих средств. «Расулия» имело два здания, одно стоимостью 70000 руб., другое 16000 руб. По инициативе Габдуррахмана Расули здесь были созданы типография, татарская библиотека, аптека, книжный магазин, открыт фонд помощи сиротам. Не случайно современники назвали этот район «Мигмария» (обустроенный). Здесь была создана классическая городская махалля, которая должна была стать моделью для общин Уральского региона и Казахстана [Хабутдинов, 2011].

Рассмотрим профессиональный профиль мусульманского населения в центрах трех основных мусульманских губерний ВолгоУральского региона: Казанской, Уфимской и Оренбургской. По переписи 1897 г., основным занятием населения в городах была торговля: Казань (15,66 \%), Уфа (21,54 \%), Оренбург (23,60 \%) и сфера услуг $(20,69 \%, 32,56 \%$, и 26,11 \% соответственно). В обрабатывающей промышленности было занято 24,51 \%, 12,53 \% и 18,82 \%. Свободными профессиями было занято 0,90 \%, 1,23 \% и 0,80 \%, в администрации $1,58 \%, 1,63 \%$ и 0,29 \%. Духовенство составляло 0,36 \%, 0,27 и 0,55 \% [Noack, 1993, Table IIa]. Таким образом, структура татарского общества включала в себя лишь незначительное количество представителей элиты в лице чиновников, лиц свободных профессий, высших слоев буржуазии и духовенства. Однако татары оставались единственным этносом среди мусульманских народов России и среди нерусских народов Волго-Уральского региона, обладавшим мобильным городским средним классом.

В 1890-е гг. у татар сформировались четыре группы национальной элиты: дворянство, духовенство, буржуазия, интеллигенция (новая группа элиты). Начиная с 1909 г. татарская буржуазия обсуждает создание национального банка (мусульманского банка России). В 1913 г. в журнале «Иктисад» («Экономика) утверждалось, что «разрешение данной проблемы будет означать и решение вопроса об экономической жизни и смерти миллионов мусульман России» [Газизуллин, 1979, с. 238-239]. В 1917 г. идея национального банка воплотилась в «Милли хэзинэ» (Национальная казна).

В 1912 г. в статье «Тюркский мир» Ю. Акчура писал, что «в современном тюркском мире возникает новая социальная сила - буржуазия (средний класс). Богатый средний класс крупных торговцев, промышленников и владельцев шахт в Баку, Оренбурге и Казани основных центрах тюрок Севера и Азербайджана - служит здесь примером. Средний класс является националистическим. Его экономические интересы требуют прогресса и развития национальной идеи и чувств. Очень быстро теоретики (идеологи) национализма 
группируются вокруг буржуазии Казани, Баку и Оренбурга». Если Стамбул является нервным центром и мозгом тюркского мира, то тюрки Казани выполняют в этом мире функции центра торговли и образования, экономически объединяя тюркский мир. Центром объединения тюркского мира Ю. Акчура видит «Тарджеман», возглавляемый И. Гаспринским: «тюркский мир России» формирует единый блок, который можно характеризовать как «рождение новой нации Востока» [Akcura, 1980, p. 121-124]. Однако эта новая индустриальная буржуазия оставалась меньшинством даже среди татарской буржуазии, к тому же в большой части она проживала вне основной зоны оседлых поселений мусульман Волго-Уральского региона. Современным городским средним классом кроме татар обладали только азербайджанцы (преимущественно в Баку) и крымские татары (но здесь прослойка была незначительной во всех смыслах). Джадиды не смогли создать общероссийской асабийи, хотя и стремились к этой цели.

10-15 апреля 1905 г. в Уфе при ОМДС под председательством муфтия М. Султанова прошло совещание «Голяма жэмгыяте» («Общества улемов»). Совещание было созвано по указанию Председателя Кабинета Министров Сергея Витте для составления официального доклада, касающегося проблемы мусульманской общины [Хабутдинов, 2010, с. 154-159]. Основным докладчиком был казый ОМДС Р. Фахретдин. Он предложил создать пост Шейх уль-Ислама, как единого лидера российских мусульман, избираемого ими самими, в ранге имперского министра. Р. Фахретдин был сторонником сосредоточения власти в руках непосредственно Духовного собрания - муфтия и казыев. В лице муфтия он видел посредника между миллетом и правителем [Биги, 1915, с. 53-56].

Риза Фахретдин представил затем детальный проект реформы ОМДС. Во введении он указывает, что «1) Религиозные дела российских мусульман находятся в ведении их духовного управления». В примечании он указывает, что религиозные дела включают в себя: «все обязанности духовенства в мечетях и медресе, контроль за мектебами и медресе, шакирдами, муаллимами, мударрисами, инспекторами (назир), рассматриваемые в религиозных судах семейные вопросы: бракосочетание, развод, алименты, наследство и другое». В четвертой главе под названием «Махкама исламия» (Духовный суд, собрание) указывается, что оно управляет вакфами (п. 37). В п. 14 указывается, что «Собрание считается инстанцией одного уровня с губернскими правлениями, поэтому оно составляет отношения в губернское правление, донесения в Министерство внутренних дел, канцелярию». В п. 16 определяются полномочия муфтия - «председатель Собрания, религиозный руководитель мусульман, их представитель перед правительством, доводящий религиозные, национальные нужды мусульман до министров, Совета Министров, Государственного совета, даже лично до самого императора» [Биги, 1915, с. 63-74]. Духовное Собра- 
ние тем самым сочетает в себе полномочия двух ветвей власти: судебной и исполнительной.

Таким образом, полномочия Собрания должны включать в себя религиозные полномочия ОМДС: назначения духовенства, строительство и ремонт мечетей. При этом Р. Фахретдин добавляет контроль над вакфами, религиозной литературой, изданием нормативно-правовых актов. В сфере просвещения оно берет в свои руки систему частного религиозного образования и назначение вероучителей в государственные школы. Документация наряду с имеющимся ведением метрических книг, списков мечетей и духовенства должна расшириться и включать в себя создание списков школ и учителей. Полномочия Собрания распространяются на социальную сферу, включая помощь сиротам и вдовам. Его решения должны проводиться в действие с помощью губернского или областного правления, полиции. Здесь выстраивается структура асабийи с избираемым лидером во главе. Причем император отбирал бы одного из трех избранных кандидатов.

Пиком мусульманского политического движения в 1905-1907 гг. является III Всероссийский Мусульманский съезд, состоявшийся 1621 августа 1906 г. в Нижнем Новгороде. По программе реформы управления духовными делами в России создавались пять Махкама-и-Исламия (Мусульманских Собраний), включая два на Кавказе, Оренбургское, Таврическое и Туркестанское. Им передавались все религиозные дела мусульман, включая контроль над медресе, мечетями и вакфами, утверждение духовных лиц и судопроизводство по вопросам никаха, талака и мираса. Средний уровень (то есть уровень ахунов) должны были составлять губернские и уездные меджлисы духовенства. Главой мусульман России избирался Раис-уль-Улама, имеющий право личного доклада императору. Все духовенство избиралось только мусульманами. Исмаил Гаспринский призвал к тому, чтобы автономию возглавили Г. Баруди и Ю. Акчура. Таким образом, муфтием должен был стать улем, а его помощником - юрист. Рекомендация Гаспринского провозгласить Раис-уль-Улама Галимджана Баруди обозначала открытый разрыв с системой официального религиозного устройства. Татарское духовенство, поддержанное буржуазией, было уже принципиально готово к переходу к религиозной автономии.

Однако в итоге религиозная автономия стала реальностью только после февральской революции 1917 г. Но вскоре большевики конфисковали частную собственность, что лишило асабийю былого округа ОМДС материальной основы. Еще один план реформ среди российских мусульман оказался нереализованным. 


\section{Список источников и литературы}

Азаматов, 1999 - Азаматов Д.Д. Оренбургское Магометанское Духовное Собрание в конце XVIIIXIX в. Уфа, 1999.

Асфандияров, 2005 - Асфандияров А.3. Кантонное управление в Башкирии (1798-1865 гг.). Уфа, 2005.

Биги, 1915 - Биги М. Ислахат асалары. Пг, 1915.

Газизуллин, 1979 - Газизуллин Ф.Г. Дорогой к правде. Казань, 1979.

Денисов, 2009 - Денисов Д.Н. Габдрахимов Г. // Ислам на Урале. Энциклопедический словарь. Москва-Н. Новгород, 2009.

Игнатенко, 1980 - Игнатенко А.А. Ибн-Хальдун. Москва, 1980.

Ислам, 1991. - Ислам: Энциклопедический словарь. Москва, 1991.

Ислам..., 2001 - Ислам в Российской империи: Законодательные акты, описания, статистика. Москва, 2001.

Мэржани, 1900 - Мэржани Ш. Ал-кисм ас-сани мин китаб мустафад ал-ахбар фи ахвал Казан ва Булгар. Казань, 1900.

Материалы..., 1960 - Материалы по истории Башкирской АССР. Т. 5. Москва, 1960.

Медресе..., 2007 - Медресе г. Казани XIX - начала XX в.: Сборник документов и материалов. Казань, 2007.

Мухетдинов, 2011 - Мухетдинов Д.В., Хабутдинов А.Ю. Мусульманские духовные лидеры России Нового времени. Н. Новгород, 2011.

Проект..., 2009 - Проект «Устава управления духовными делами магометан» 1867 г. оренбургского муфтия С. Тевкелева // Эхо веков. 2009. № 1.

Салихов, 2001 - Салихов Р.P. Мусульманская благотворительность и проблема формирования общинного самоуправления // Ислам в Среднем Поволжье: История и современность: Очерки. Казань, 2001.

Салихов, 2006 - Салихов P.P. Участие татарского предпринимательства в общественно-политических процессах второй половины XIX - начале XX в. Казань, 2006.

Фахретдин, 1904 - Фахретдин Р. Асар. 1 жилд. 5 жозья. Оренбург, 1904.

Фахретдин, 1917 - Фахретдин Р. Шэех Зайнулла хэзретенен тэржемэи хэле. Оренбург, 1917.

Фахретдин, 2005 - Фахретдин Р. Асар. Т. 1. Казань, 2005.

Хабутдинов, 2010 - Хабутдинов А.Ю. История Оренбургского Магометанского Духовного Собрания (1788-1917): институты, люди, идеи. Москва-Н. Новгород, 2010.

Хабутдинов, 2011 - Хабутдинов А.Ю. К 130-летию со дня рождения муфтия Габдуррахмана Расули // Ислам Минбаре. 2011. №191.

Akcura, 1980 - Akcura Y. Le monde Turc // Georgeon F. Aux origines du nationalisme Turc: Yusuf Akcura (1876-1935). Paris, 1980.

Noack Ch. Die ethnisch-soziale Struktur der Wolgatataren nach der russischen Volkszahlung von 1897. Magisterarbeit Universität Köln. Köln, 1993. Table IIa. 